TECHNICAL DIVISION

SAVANNAH RIVER LABORATORY

DPST $-88-793$

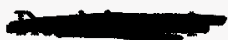

November 3, 1988

To.

FROM:

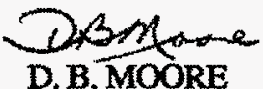

RECEIVED

JUN 251998

OSTI

\title{
MUTIGATION_ALTERNATIVES FOR_LAKE
}

\section{SUMMARY}

The current condition of $\mathrm{L}$ Lake/Steel Creek was summarized in a report to \$CDHEC in June 1988 which reported that the L Lake and Steel Creek ecosystems were adequately developing towards balanced biological communities. If mitigation for L Lake inputs, specifically temperature and nutrients, are required, several viable alternatives are available. A report prepared by Spencer in 1986 discusses the various options available for cooling L-Reactor discharges. In effect, a small cooling tower is the only realistic solution to reducing effluent temperatures. Nutrient mitigation can take several approaches including upstream sewage treatment, hypolimnetic withdrawal, dilution of input water by Par Pond water, precipitation of nutrients, and sediment oxidation. None of these systems would influence the thermal regime, but would significantly reduce nutrient input into the system. One beneficial use of L-Lake thermal effluents is algaculture, the production of useful algae. A document prepared in 1988 concludes that algaculture is a technically and economically feasible mitigation alternative for $L$ Lake and could allow L Lake to be handled under Section 318 of the Clean Water Act.

\section{INIRODUCTION}

L Lake was built in 1985 to receive and cool the themal effluents from the L-Reactor. The lake was constructed by impounding approximately $7 \mathrm{~km}$ of the upper portions of Steel Creek to form a 1000-acre reservoir. Dam construction and reservoir filling were completed in October 1985 and L-Reactor resumed operations at the end of the same month. Since 1985, this system has been developing a biological community comprised of representatives of all trophic levels. The system is impacted by both temperature from the operating reactor and nutrient inputs from the Savannah River ecosystem. A preliminary evaluation of the technical and monctary feasibilities of a number of thermal and/or nutrient mitigation alternatives for the L-Lake ecosystem has been performed by the Ecology Group of SRL/ESD. This report is a summary of the alternatives considered and their applicability.

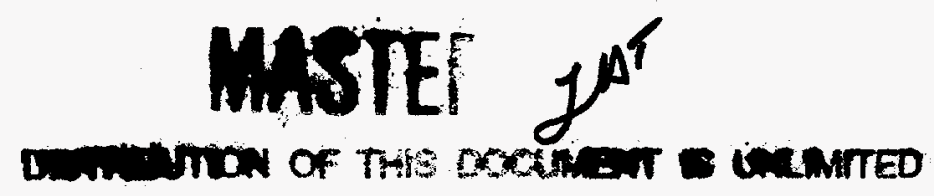




\section{DISCLAIMER}

This report was prepared as an account of work sponsored by an agency of the United States Government. Neither the United States Government nor any agency thereof, nor any of their employees, makes any warranty, express or implied, or assumes any legal liability or responsibility for the accuracy, completeness, or usefulness of any information, apparatus, product, or process disclosed, or represents that its use would not infringe privately owned rights. Reference berein to any specific commercial product, process, or service by trade name, trademark, manufacturer, or otherwise does not necessarily constitute or imply its endorsement, recommendation, or favoring by the United States Government or any agency thereof. The views and opinions of authors expressed herein do not necessarily state or reflect those of the United States Government or any agency thereof. 


\section{DISCLAIMER}

Portions of this document may be illegible in electronic image products. Images are produced from the best available original document. 
J. C. COREY

Page 2

November 3, 1988

\section{DISCUSSION}

\section{Current Condition}

A 316(a) Demonstration for the $L$ Lake/Steel Creek was issued and submitted to SCDHEC in June 1988 (Gladden, et al. 1988). This teport documented that both the L Lake and Steel Creek ecosystems were adequately developing towards balanced biological communities $(\mathrm{BBC})$. Since the majority of the biomonitoring for this study was con ucted under reduced power level operations in L-Reactor, work has been initiated to ensure that increased power levels do not negatively impact $B B C$ development and maintenance.

\section{Mitigation Areas}

\section{Supplemental Cooling}

Previous studies conducted to evaluate cost-effective ways of supplementing L-Lake cooling to reduce the L-Reactor power loss associated with discharge compliance indicated that the use of cooling towers is the only feasible, costeffective way to significantly improve reactor power and that various lake enhancement options, e.g. barrier curtains and floating mixers can provide some thermal mitigation (Menna, 1986; Spencer, 1986). Because of the extent and quality of these studies, no additional supplemental cooling measures were considered in the ESD evaluation.

\section{Nutrient Mitigation}

The theoretical and empirical background for nutrient mitigation in $L$ Lake has been synthesized and documented in DPST-88-707, A Review of Abiotic and Biotic Interactions in Pelagic Communities: Processes Relevant to L Lake, by J. A. Bowers. This report describes the limnology of pelagic communities, the role of phosphorus and nitrogen in reservoir eutrophication, and nutrient limitations on algal growth and reproduction, including nutrient kinetic models and the abiotic and biotic interactions between the different trophic levels and extrapolates these results to $L$ Lake. With an understanding of the ecosystem's structure and function, other mitigation alternatives have been identified that can yield environmental benefits at greatly reduced costs. These alternatives include the following:

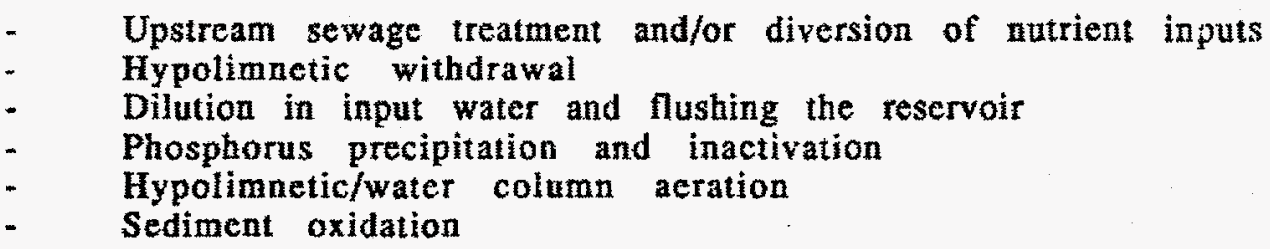

Addition of lime treatment facilities to the Augusta sewage treatment plant was evaluated and documented in DPST-88-747, Capital Costs of Lime Treatment at the Augusta Wastewater Treatment Plant, by N. V. Halyerson. The results of the 


\section{J. C. COREY.}

Page 3

November 3, 1988

DPST-88-793(Rev 1)

study indicate that lime treatment of the sewage would reduce the phosphorus levels of the effluent disckarged to the Savannah River, thereby reducing the phosphorus loading of $L$ Lake. Primary lime treatment, involving the addition of low lime dosages to the infuent wastewater upstream of the primary setting basin, would result in a total phosphorus removal of approximately $80 \%$, a $60-70 \%$ reduction of the biochemical oxygen demand, and a reduction in total suspended solids, at an estimated total cost of between $\$ 500,000$ and $\$ 3$ million. Tertiary lime treatment, consisting of lime addition to the cffuent from conventional secondary treatment, would result in even lower effluent phosphorus levels, bat with an estimated capital cost expenditure of \$5-14 million.

The other alternative measures identified have been used in other reservoir systems. Preliminary investigations indicate that hypolimnetic withdrawal and/or aeration show promise as mitigation options for $L$ Lake and will therefore be pursued further.

\section{Beneficial Uses}

\section{Algaculture}

Due to the large costs associated with the current L-Reactor operating restraints required to meet NPDES permit requirements and the large capital expenditures associated with cooling towers, an assessment of potential altemative mitigation technologies was undertaken. Algaculture, which beneficially utilizes heat and the nutrients from the reactor cooling water discharge, was cvaluated because both temperature and nutrient levels in L Lake would be significantly reduced and such a project could exempt the upper portion (300 acres) of the lake from State Class B temperature limits per Section 318 of the Clean Water Act. DPST-88-588, A Proposed Algaculture Facility At L Lake, by E. W. Wilde and J. R. Benemann, documents the initial investigation of this technology. It was concluded in this report that algaculture is a technically and economically feasible, environmentally sound Initigation alternative for $\mathrm{L}$ Lake.

\section{CONOLUSIONS}

To mitigate thermal discharges, a supplemental cooling tower appears to be the most feasible option. To reduce nutrients, upstream nutrient removal, preferably near the Augusta water treatment plant, would be required. It is recognized, however, that this removal of nutrients is unlikely to totally eliminate nutrients from the Savannah River and thus there will always be an excess of nutrients in the L-Lake system. Preliminary investigations also indicate that it may be possible to request a variance under Section 318 of the Clean Water Act so that $L$ Lake could be used as an algaculture facility. This approach would permit the beneficial use of the excess heat and nutricnts in the system.

\section{DBM:bE}




\section{J. C. COREY}

Page 4

November 3, 1988

DPST-88-793(Rev 1)

\section{References:}

1. DP-1766, Compliance of the Savannah River Plant L-Reactor Cooling System With Environmental Regulations, J. B. Gladden, W. L. Specht, J. A. Bowers, N. V. Halverson, H. E. Mackey, and E. W. Wilde, 6/30/88.

2. DPE-3786, Supplemental Cooling - L Reactor, Effluent Report of Cooling Options and Life Cycle Costs, C. D. Spencer, 10/15/86.

3. DPST-88-588, A Proposed Algaculture Facility At L Lake, E. W. Wilde and J. R. Benemann, 11/18/88, in draft.

4. DPST-88-747, Capital Costs of Lime Addition at the Auguste Wastewater Treatment Plant, N. V. Haiverson, 8/17/88.

5. Memorandum, J. A. Bowers to D. B. Moore, L-Lake Mitigation Tasks for DOE, 8/4/88.

6. DPST-88-707, A Review of Abiotic and Biotic Interactions in Pelagic Communities: Processes Relevant to L Lake, J. A. Bowers, 8/1/88.

7. DPST-88-739, L Lake Stratification During Mk-22 Operation, J. B. Gladden, 7/29/88. 